\title{
A Review of Factors Affecting Nursing Turnover in Japan
}

\author{
Yoshiyuki Nagaya* \\ Kansai University of Social Welfare, Japan
}

Received: 濫: November 29, 2018; Published: 䒸: December 20, 2018

*Corresponding author: Yoshiyuki Nagaya, Kansai University of Social Welfare, 380-3 Shinden, Ako, Hyogo 678-0255, Japan

\section{Abstract}

Background: High turnover among Japanese nurses is a significant issue. In 2012,191,000 nurses joined the profession, while up to 161,000 left. If this trend continues, healthcare service delivery could be severely impacted. However, it is not clear why Japanese nurses leave the profession. There are no systematic reviews clarifying the complex interrelated personal, organizational, and socio-cultural factors that contribute to nurse turnover in Japan. Such insight may help when developing policies in response to this public health issue.

Objective: This study aimed to identify factors affecting Japanese nurses' intention to leave their current position and/or the career as a whole.

Methods: A structured review was conducted by researching primary research articles (in English-speaking journals) between 2006 and 2016 Four databases and Google Scholar were used to identify quantitative and qualitative studies focused on describing factors contributing to nursing turnover in Japan. Papers were screened and appraised using appropriate tools. A narrative synthesis was applied to papers included in the review. A thematic analysis was conducted on the findings from each paper.

Results: Ten papers were included in the review. Three themes emerged: personal factors, socio-cultural factors, and organizational factors. Relationships between these factors were identified, including associations with burnout and job dissatisfaction. Key factors contributing to job dissatisfaction and burnout included perceived unsuitability to the job, poor work environment, inadequate quality of care, low remuneration, and inexperience.

Conclusion: Various strategies may be implemented to address nurses' intent to leave, including career development and training, flexible working arrangements, improved interpersonal relationships in the workplace, recognition of one's work, health and wellness courses, and other educational programmers. Generalization regarding each particular nurse's decision to leave his or her job, or the profession, is difficult to make. The interplay between various subjective and objective factors needs to be considered.

Keywords: Burnout; Intent to Leave; Japan; Job Dissatisfaction; Nurse; Turnover

\section{Introduction}

At present, the Japanese health system, like most countries, significantly depends on nurses delivering quality care to individuals, families, and communities. Nurses comprise the majority of health professionals in Japan; Table 1 shows that out of $2,029,242$ health professionals, almost $70 \%$ are nurses (including both registered and enrolled nurses). Thus, nursing shortages can prove costly and detrimental to a nation's health system [1]. Closely related to nursing shortages is nursing turnover, which can negatively impact the health sector's capacity to satisfy patient needs and provide quality care [2]. A high turnover rate can affect nurses' wellbeing and productivity [3]. Hence, for these reasons, a continuous supply of nurses is imperative to the wellbeing and progress of Japanese society. A better understanding regarding nursing turnover is necessary to adequate address this growing problem. Thus, the present paper includes a systematic review of nursing turnover in Japan.
Table 1: Employed health professionals in 2012.

\begin{tabular}{|c|c|c|}
\hline Profession & Number & Percentage \\
\hline Registered nurses & $1,015,744$ & $50 \%$ \\
\hline Enrolled nurses & 357,777 & $18 \%$ \\
\hline Physicians & 303,268 & $15 \%$ \\
\hline Dental hygienists & 108,123 & $5 \%$ \\
\hline Dentists & 102,551 & $5 \%$ \\
\hline Public health nurses & 47,279 & $2 \%$ \\
\hline Dental technologists & 34,616 & $2 \%$ \\
\hline Midwives & 31,835 & $2 \%$ \\
\hline Pharmacists & 28,052 & $1 \%$ \\
\hline Total & $2,029,242$ & $100 \%$ \\
\hline
\end{tabular}

Source: Ministry of Health, Labor and Welfare n.d. 


\section{Definition of Key Variables and Relationships}

Turnover refers to the movement of individuals within an organization, profession, or industry. In general, turnover is understood as the rate at which employees leave a company or organization and are replaced by new people [4]. A high nurse turnover rate has been associated with dissatisfaction [5]. Job satisfaction refers to how a person feels about various aspects of his or her employment [6] and has been identified as a factor contributing to an employee's intent to leave and job turnover [7]. "Intent to leave" refers to an employee's plan to quit his or her existing job and/or find another job, whether in the same or different profession [4]. The intent to leave is a critical factor in predicting nursing turnover [8]. Turnover is highly related to burnout, which is linked to job dissatisfaction. Burnout is the severe physical, emotional, and mental fatigue experienced by individuals on the job. Nurses, for example, are at high risk for burnout due to the intense nature of providing multi-pronged medical care [9].

\section{Turnover and Nurse Availability}

The number of nurses has increased in Japan. Between 2002 and 2014 , nurse employment rose by $30 \%$, from $1,163,393$ to $1,506,380$; however, this was not sufficient to meet the nursing demand of 1,623,800 in 2014 [10-12]. By 2025, it is estimated that nursing demand will rise to $1,844,000$. However, the nurse supply is expected to remain short of this demand [13], especially within small and medium-sized hospitals. Competition for nurses tends to result in larger hospitals paying higher salaries and attracting a greater number of nurses than smaller ones [14]. Due to the discrepancy between nursing supply and demand, concerns over shortages have risen. According to statistics from 2012, roughly 191,000 registered nurses joined the profession, which includes around 47,000 newly qualified nurses (and around 144,000 with prior experience rejoining the workforce or transferring). However, roughly 161,000 left the profession, with turnover being higher in large cities [15]. Throughout Japan, this nursing shortfall creates several healthcare delivery challenges. This is even more problematic as the gap between supply and demand is not estimated to decrease any time soon [15].

This nursing shortage in Japan is primarily the product of high turnover. However, high nurse turnover is not just a problem in Japan. Other countries, such as the United States, Great Britain and Germany, are also dealing with this issue [16-20]. Research into the factors contributing to nursing shortages, and strategies to address such shortages, is needed. Currently, there is no synthesis of evidence available to help guide strategies for preventing nursing turnover. Thus, the goal of the present paper was to conduct a review of published reports describing the factors contributing to nursing turnover in Japan.

\section{Methods}

CINAHL, MEDLINE, ProQuest Health \& Medical Collection, PubMed and Google Scholar were used to conduct a regimented literature review. Papers published between 2006 and 2016 were analyzed to determine relevancy. Papers were chosen from this time period since work environments dramatically change each year, and new technology continues to be introduced. Therefore, it seemed appropriate to review papers published in the last ten years in order to have an overview of changing contexts, as well as current factors, affecting nursing turnover in Japan. The following search terms were used: 'intent to leave', 'turnover', 'burnout', 'job dissatisfaction', 'nurse' and 'Japan'. The last date of access for all databases was 1-6-2017. In the case of Google Scholar, the number of hits was inordinately high; therefore, another search was conducted combining the keywords, which yielded 204 papers for possible inclusion (Table 2). To assure review quality, PRISMA guidelines [21] were employed. During identification, 500 papers were initially deemed relevant, including nine additional papers culled from the reference lists of retrieved papers. During the screening process, duplicate and irrelevant papers (determined by assessing titles and abstracts) were excluded.

Table 2: Records retrieved from sources.

\begin{tabular}{|c|c|c|c|c|c|}
\hline & CINAHL & MEDLINE & ProQuest Health \& Medical Collection & PubMed & Google Scholar \\
\hline "Intent to leave:\& Nurse \& Japan & 2 & 1 & 1 & 12 & 16900 \\
\hline “Turnover"\& Nurse \& Japan & 19 & 14 & 4 & 128 & 11200 \\
\hline "Burnout"\& Nurse \& Japan & 30 & 26 & 6 & 59 & 6920 \\
\hline "Job dissatisfaction" "\& Nurse \& Japan & 2 & 2 & 1 & 6 & 17400 \\
\hline Total & 53 & 43 & 12 & 205 & 52420 \\
\hline
\end{tabular}

During the eligibility process, full-text articles were assessed. Consequently, 10 studies were included in this review. Table 2 details the number of papers initially retrieved through database searches, while (Figure 1) highlights the screening process, with a detailed number of references based on PRISMA guidelines. A metaanalysis was initially considered for the present review; however, as the included studies were highly heterogeneous, an adequate meta- analysis could not be pursued. Consequently, a narrative synthesis methodology [22] was applied. Therefore, the results section of each paper was considered thematically, and common themes were determined. Furthermore, to assure review quality and to avoid bias, qualitative studies were assessed applying the Critical Appraisal Skills Programmed method [23], and non-experimental studies were assessed using Law's Critical Review Form [24]. 


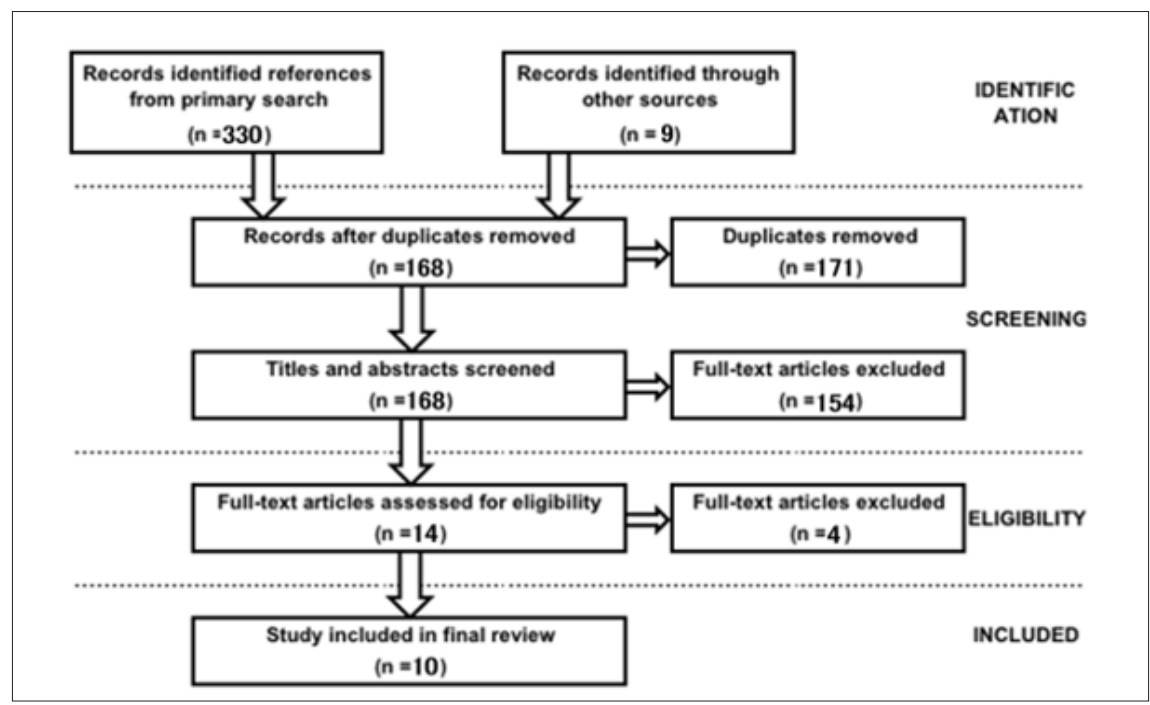

Figure 1: Preferred reporting diagram for systematic reviews \& meta-analyses (PRISMA) showing selection for review.

\section{Results}

A summary of the reviewed studies is shown in Table 3. Five of the 10 papers were quantitative, four were qualitative, and one paper employed mixed methods. The papers covered a range of settings, including urban and rural hospitals with different bed capacities (ranging from 50 to 700 beds). The present results are described according to key variables of interest, including intent to leave, turnover, burnout, and job dissatisfaction. Across all papers, factors contributing to nurses quitting their job and/or their profession are discussed. Each paper addresses factors leading to a job/career exit and the main factors impacting the exit. A thematic analysis was identified as contributing to nurses' decision to leave either their job or, more significantly, the profession. These factors are outlined in Figure 2.

Table 3: Summary of studies included in the synthesis.

\begin{tabular}{|c|c|c|c|c|}
\hline Reference & Institution \& participants & Methodology & Sample \& duration & Aim \\
\hline $\begin{array}{l}\text { Ishihara et al. } \\
\qquad \text { [32] }\end{array}$ & $\begin{array}{l}\text { Newly graduated nurses } \\
\text { from baccalaureate pro- } \\
\text { grams and diploma schools } \\
\text { from } 19 \text { public medical } \\
\text { institutions, with more than } \\
300 \text { beds. }\end{array}$ & $\begin{array}{l}\text { Newly graduated nurses from bacca- } \\
\text { laureate programs and diploma schools } \\
\text { from } 19 \text { public medical institutions, with } \\
\text { more than } 300 \text { beds }\end{array}$ & $\begin{array}{l}762 \text { graduate nurses } \\
\text { commencing job in } 2010 . \\
\text { Survey took about eight } \\
\text { weeks to complete }\end{array}$ & $\begin{array}{l}\text { To investigate intention to } \\
\text { leave due to organizational } \\
\text { factors and work environ- } \\
\text { ments of nurses. }\end{array}$ \\
\hline Kanai-Pak et al. & $\begin{array}{l}19 \text { acute care hospitals } \\
\text { including } 15 \text { university } \\
\text { hospitals, mainly in Kanto. } \\
\text { Some hospitals in Hokkaido, } \\
\text { Kyushu and west Japan. }\end{array}$ & $\begin{array}{l}\text { Quantitative method. Nursing Work } \\
\text { Index-Revised applied. }\end{array}$ & $\begin{array}{c}5956 \text { staff nurses in } 302 \\
\text { units. Study conducted be- } \\
\text { tween March and October } \\
\text { 2005. 84\% response rate. } \\
\text { Excluded obstetrics and } \\
\text { psychiatry units. }\end{array}$ & $\begin{array}{l}\text { To examine nurse burnout, } \\
\text { job dissatisfaction and } \\
\text { quality of care in Japanese } \\
\text { hospitals and to determine } \\
\text { how these results are } \\
\text { linked to work environ- } \\
\text { ment factors. }\end{array}$ \\
\hline Kudo et al. [28] & $\begin{array}{l}\text { Registered nurses, licensed } \\
\text { practical nurses and assis- } \\
\text { tant nurses working full time } \\
\text { in four small and medi- } \\
\text { um-sized medical institu- } \\
\text { tions ( } 51 \text { to } 161 \text { beds). }\end{array}$ & $\begin{array}{l}\text { Qualitative method. Self-administered } \\
\text { questionnaire survey. Multiple linear } \\
\text { regression analysis applied. }\end{array}$ & $\begin{array}{c}293 \text { nurses. Effective } \\
\text { response rate } 57.3 \% .15 \\
\text { males and } 153 \text { females, } \\
\text { with average age of } 35.8 \\
\text { years. Study conducted in } \\
2005 .\end{array}$ & $\begin{array}{l}\text { To analyses considerations } \\
\text { linked to turnover inten- } \\
\text { tion among nurses in small } \\
\text { and medium-sized medical } \\
\text { institutions. }\end{array}$ \\
\hline $\begin{array}{l}\text { Ohue, Moriyama } \\
\text { \& Nakaya[5] }\end{array}$ & $\begin{array}{l}\text { Eight random hospitals } \\
\text { providing acute medical } \\
\text { treatment in Kansai district. }\end{array}$ & $\begin{array}{c}\text { Qualitative method. Survey included } \\
\text { evaluation of burnout (Maslach Burnout } \\
\text { Inventory), stress (Nursing Job Stressor } \\
\text { Scale), automatic thoughts (Automatic } \\
\text { Thoughts Questionnaire-Revised) and } \\
\text { irrational beliefs (Japanese Irrational } \\
\text { Belief Test), in addition to intention to } \\
\text { resign. }\end{array}$ & $\begin{array}{l}445 \text { nurses working < five } \\
\text { years at three hospitals } \\
\text { with several departments } \\
\text { for acute treatment. } \\
\text { Effective response rate } 336 \\
\text { ( } 27 \text { male and } 309 \text { female). } \\
\text { Study performed in Octo- } \\
\text { ber and November } 2008 .\end{array}$ & $\begin{array}{c}\text { To develop a cognitive } \\
\text { model of stress, burnout } \\
\text { and intention to resign for } \\
\text { nurses. }\end{array}$ \\
\hline
\end{tabular}




\begin{tabular}{|c|c|c|c|c|}
\hline $\begin{array}{l}\text { Suzuki et al. } \\
\quad[30]\end{array}$ & $\begin{array}{c}\text { Full time novice nurses } \\
\text { (nurses, public health nurses } \\
\text { and midwives) at hospitals } \\
\text { with }>400 \text { beds (excluding } \\
\text { psychiatric hospitals). }\end{array}$ & $\begin{array}{l}\text { Quantitative method. Demographic attri- } \\
\text { butes, burnout (That is, Japanese version } \\
\text { of Maslach Burnout Inventry (J-MBI)) } \\
\text { and assertiveness (That is, Japanese ver- } \\
\text { sion of Rathus Assertiveness Schedule } \\
\text { (J-RAS)) and perceptions were analyzed. }\end{array}$ & $\begin{array}{l}\text { 1,203 full time novice } \\
\text { nurses who started } \\
\text { nursing careers in one } \\
\text { of } 20 \text { hospitals in } 2003 . \\
\text { Two-year study of univer- } \\
\text { sity hospitals in 2001/02 } \\
\text { Hospital Catalogue in } \\
\text { Japan. 1,030 nurses re- } \\
\text { sponded (85.6\% response } \\
\text { rate). Effective response } \\
965 \text { nurses ( } 93.7 \%, 932 \\
\text { females and } 33 \text { males). }\end{array}$ & $\begin{array}{l}\text { To examine factors affect- } \\
\text { ing turnover of new nurses } \\
\text { during 10th-15th months } \\
\text { of employment compared } \\
\text { to during preceding six } \\
\text { months. }\end{array}$ \\
\hline $\begin{array}{c}\text { Takase, Nakay- } \\
\text { oshi \& Teraoka } \\
\text { [31] }\end{array}$ & $\begin{array}{c}\text { Five hospitals in Japan's } \\
\text { western region. } 2011 \text { gradu- } \\
\text { ate nurses with no previous } \\
\text { experience in nursing (in- } \\
\text { cluding work experience as a } \\
\text { licensed practical nurse). }\end{array}$ & $\begin{array}{l}\text { Quantitative method. Analyzed using } \\
\text { multiple regression analysis. A longitudi- } \\
\text { nal study design was used to investigate } \\
\text { changes in graduates' perceptions of } \\
\text { demands-abilities and supplies-needs } \\
\text { misfits and impact on turnover intention. }\end{array}$ & $\begin{array}{l}279 \text { graduate nurses. } \\
\text { Study conducted in } 2011, \\
\text { three, six, nine and twelve } \\
\text { months after nurses' em- } \\
\text { ployment began. }\end{array}$ & $\begin{array}{l}\text { To investigate how grad- } \\
\text { uate nurses' perceptions } \\
\text { of the demands-abilities } \\
\text { and supplies-needs misfits } \\
\text { changed over time, and to } \\
\text { examine how these misfits } \\
\text { impact their intention to } \\
\text { leave the jobs. }\end{array}$ \\
\hline $\begin{array}{l}\text { Takase, Oba \& } \\
\text { Yamashita [25] }\end{array}$ & $\begin{array}{c}\text { Registered nurses at three } \\
\text { medium to large public } \\
\text { hospitals (one university, } \\
\text { one prefectorial and one city } \\
\text { hospital, with between } 430 \\
\text { and } 700 \text { beds) in Japan's } \\
\text { western region. }\end{array}$ & $\begin{array}{l}\text { Mixed methods (a survey method was } \\
\text { used to collect quantitative and qualita- } \\
\text { tive data). Survey method used to collect } \\
\text { quantitative and qualitative data. Quanti- } \\
\text { tative data analyzed by ANOVA, and qual- } \\
\text { itative data analyzed by content analysis. } \\
\text { Explanatory comparative design with a } \\
\text { cross-sectional survey method used. }\end{array}$ & $\begin{array}{l}849 \text { registered nurses. } \\
\text { Study conducted over four } \\
\text { weeks. }\end{array}$ & $\begin{array}{l}\text { To determine specific } \\
\text { work-related needs and } \\
\text { values of nurses in three } \\
\text { generations (born in } \\
\text { 1946-1959, 1960-1974, } \\
\text { 1975-present) and gener- } \\
\text { ation-specific reasons that } \\
\text { might make nurses consid- } \\
\text { er leaving the jobs. }\end{array}$ \\
\hline $\begin{array}{c}\text { Takase, Ya- } \\
\text { mashita \& Oba } \\
{[25]}\end{array}$ & $\begin{array}{c}\text { Registered nurses and } \\
\text { individuals holding both } \\
\text { midwifery and nursing qual- } \\
\text { ifications. Participants came } \\
\text { from three public hospitals, } \\
\text { of medium to large size, from } \\
\text { Japan's central-west region. }\end{array}$ & $\begin{array}{l}\text { Quantitative method. Data was examined } \\
\text { applying regression analysis. }\end{array}$ & $\begin{array}{l}849 \text { participants. Study } \\
\text { conducted in } 2006 .\end{array}$ & $\begin{array}{l}\text { To examine how nurses' } \\
\text { work values, perceptions of } \\
\text { environmental character- } \\
\text { istics and organizational } \\
\text { commitment are related to } \\
\text { their leaving intentions. }\end{array}$ \\
\hline $\begin{array}{l}\text { Tei-Tominaga \& } \\
\text { Miki [26] }\end{array}$ & $\begin{array}{l}\text { Newly graduated nurses in } \\
\text { nine advanced treatment } \\
\text { hospitals, being mainly uni- } \\
\text { versity hospitals, in Japan on } \\
\text { two separate occasions. }\end{array}$ & $\begin{array}{l}\text { Quantitative method. 22-item Job } \\
\text { Content Questionnaire was used and a } \\
\text { cluster sampling method. Longitudinal } \\
\text { design. }\end{array}$ & $\begin{array}{l}567 \text { newly graduated } \\
\text { nurses. Response rate } 301 \\
\text { nurses. Hierarchical multi- } \\
\text { ple regression analysis was } \\
\text { applied to examine factors } \\
\text { associated with intentions } \\
\text { to leave. Study conducted } \\
\text { in two phases, approxi- } \\
\text { mately six months apart. }\end{array}$ & $\begin{array}{l}\text { To consider predictors of } \\
\text { intention to leave among } \\
\text { newly graduated nurses } \\
\text { early in their careers in } \\
\text { Japan. }\end{array}$ \\
\hline $\begin{array}{l}\text { Ushiro \& Na- } \\
\text { kayama [33] }\end{array}$ & $\begin{array}{c}\text { Full time female nurses } \\
\text { working in non-managerial } \\
\text { nurses at three large, }>600 \\
\text { bed capacity hospitals. }\end{array}$ & $\begin{array}{l}\text { Qualitative method Structural equation } \\
\text { modeling applied. }\end{array}$ & $\begin{array}{l}\text { 1,131 nurses. Respons- } \\
\text { es 1,027 (response rate } \\
90.8 \% \text { ). Effective respons- } \\
\text { es for analysis } 798 \text { (valid } \\
\text { response rate } 70.6 \% \text { ). } \\
\text { Survey completed in } 2001 .\end{array}$ & $\begin{array}{l}\text { To analyses correlation be- } \\
\text { tween gender role attitudes } \\
\text { of nurses and burnout, per- } \\
\text { ceptions of physician-nurse } \\
\text { collaboration, evaluation of } \\
\text { care, and intent to continue } \\
\text { working. }\end{array}$ \\
\hline
\end{tabular}




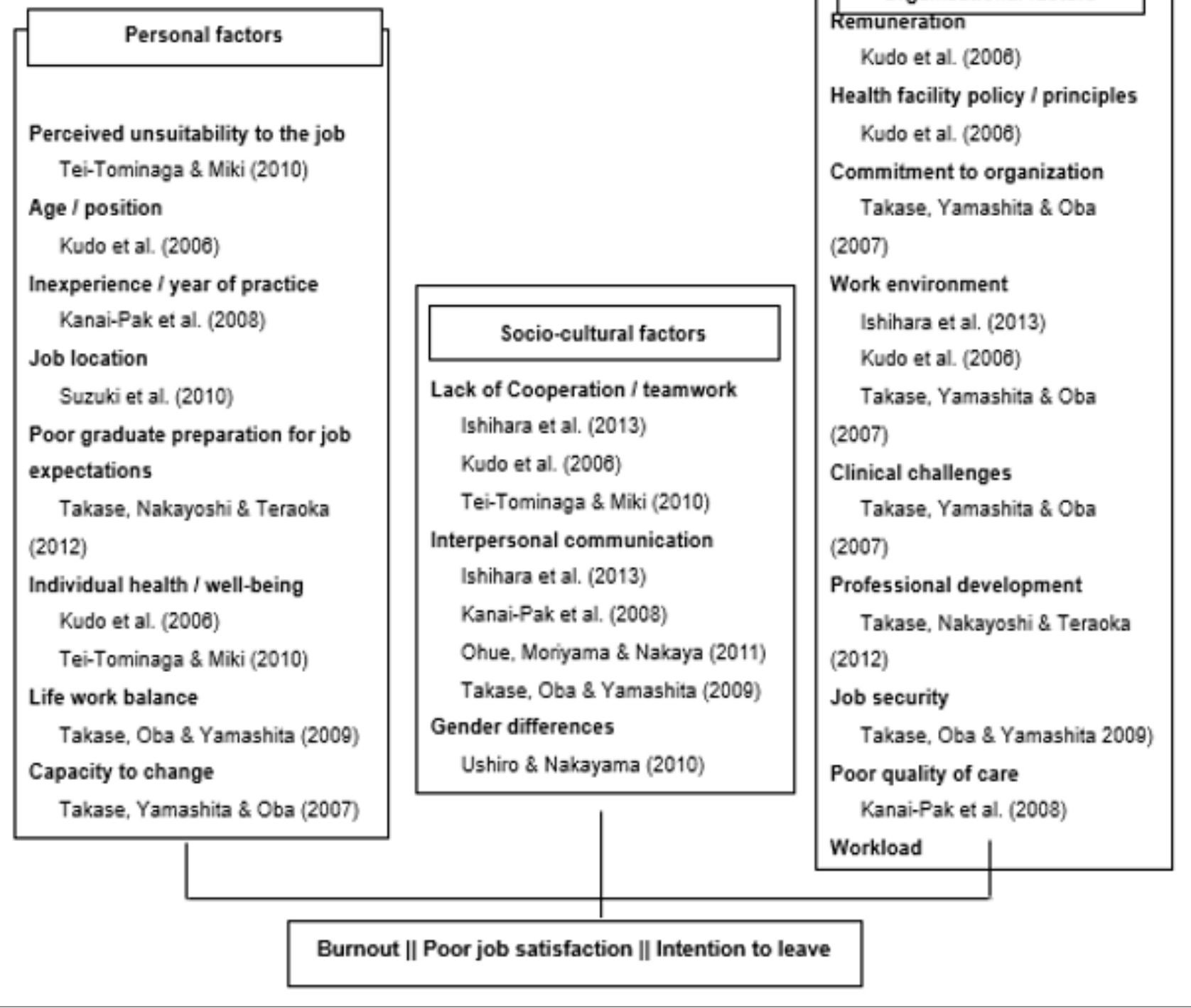

Figure 2: Factors associated with burnout, poor job satisfaction or intention to leave.

\section{Personal Factors}

Perceived unsuitability to the job: When a nurse believes he or she is unsuitable to his or her profession, he or she is likely to leave not only the job but also the profession [25]. While many individuals pursue nursing during their university studies, realities of the job or profession can lead to reservations regarding this chosen career path. Unsuitability to the job or profession has been identified as leading to nurse turnover, especially among newly graduated nurses [26-30]. A lack of understanding regarding the role of a nurse also appears to contribute to one's intent to leave [31].

Age and Position: Age has been identified as a factor affecting an individual's values at work and attitude toward his or her nursing role. Individuals of different ages have different value systems, and these value systems impact reasons for leaving an organization and/or profession [32]. For younger nurses born after 1975, losing confidence in their ability to care for patients seems to contribute to the intent to leave. Rank also appears to affect the intent to leave. For instance, more senior nurses are less likely to leave the profession [33]. Younger and more junior nursing professionals are more likely to leave their job and/or profession.

Inexperience: A nurse's experience level also influences the intent to leave. Experience is also linked to other contributing factors such as burnout and job dissatisfaction. For instance, one study observed that burnout, work dissatisfaction and low quality of care were rather high across hospitals where $50 \%$ of the nursing 
workforce was relatively inexperienced (i.e., less than 10 years' experience) compared to hospitals that have a $20 \%$ inexperienced workforce [34].

Job Location: The highest rate of job resignations occurs in Tokyo [35]. This may be due to higher professional mobility among nurses in Tokyo. Since only one study has observed this phenomenon, further research is needed to assess reasons for why nurses are leaving the profession altogether within major metropolitan areas in Japan. Poor preparation for job expectations: Another factor contributing to nurses leaving the profession is their lack of preparation for their job. When a nurse graduate is not well prepared for the profession, concerns arise, which can ultimately lead to the desire to leave [36].

Health and Well-Being: An individual's mental, physical, and/ or general health may also impact the intent to leave a job and/or profession. In an analysis of newly graduated nurses, a study found that one's own subjective health status (e.g. psychological distress or cumulative fatigue) significantly predicted the intention to leave, independent of demographic variables, stress or nursing skills [37]. Specifically, a lack of sleep has been identified as significantly predicting higher turnover [38].

Work/Life Balance: The ability to balance life and work also appears to be valued by nurses and may be impacting a desire to leave the profession. In particular, nurses born from 1960 to 1974 place a premium on the balance between their personal and professional life [39]. An imbalance may, therefore, contribute to nurses' decisions to move to another line of work .

Capacity to Change: When there is a match between the importance nurses place on being able to challenge current clinical practices and actual opportunities to do so, intentions to leave diminish; however, when there is a mismatch, intentions to quit strengthen.

\section{Socio-Cultural Factors}

Lack of Co-Operation and Teamwork: A lack of co-operation and/or teamwork has been highlighted in several studies as impacting nurses' intent to leave and turnover. Newly graduated nurses, for instance, highly value the level of support they receive from colleagues and supervisors. Nearly $10 \%$ of newly graduated nurses indicate a desire to leave nursing. Critical to this decision is whether nurses receive adequate social support from colleagues and supervisors. Organisational support can reduce burnout and contribute to job satisfaction, thus increasing commitment to the job and profession as a whole. Similarly, colleagues and supervisors play a critical role in nurse turnover. For instance, one study found that among hospitals with fewer than 500 beds, managerial and co-worker support significantly determined nurses' intent to leave. Those nurses also stated that management styles and attitudes contributed to their intent to leave. Social support from peers, through a strong and interpersonal work ethic, was also highlighted as reducing the intent to leave.

Interpersonal Communication: Studies have also shown that difficulties in interpersonal communication between nurses of different ages can result in disputes. Intergenerational factors impact nurse turnover and play a role in understanding motivations behind turnover and developing an improved work environment for all nurses. Another study also suggests that poor cooperation among nurses affects nurse turnover. In excess of $50 \%$ of nurses in one study indicated that cooperation at work between nurses and doctors was either lacking or non-existent. Furthermore, ineffective cooperation and communication between nurses and/or conflict with supervisors is related to burnout. Together, these issues can contribute to nurses' intent to leave and turnover. Finally, another dynamic to interpersonal relationships is gender differences and/or conservative attitudes, which further impact professional collegiality.

Gender Roles: In Japan, as in other countries, women have traditionally dominated the nursing profession. Perceptions of (and actual) gender roles impact the intent to leave and nursing turnover. For instance, conservatism within the health profession has been highlighted as more negatively impacting women in terms of burnout relative to men. Health professionals with patriarchal attitudes treat women nurses as subservient, resulting in added stress and fatigue. These rigid gender roles can be key to women leaving the nursing profession.

\section{Organizational Factors}

Remuneration: Actual remuneration, and a lack of transparency regarding remuneration reviews, may also be impacting turnover among nurses. In one study, nurses reported being dissatisfied with their salary and poor implementation of policies necessary to facilitate fair salary increases. Remuneration appears to be important based on historical factors. For instance, among individuals born after 1960, remuneration was more important relative to those born between 1946 and 1959. This could result from a lack of recognition or autonomy often perceived among nurses born between 1960 and 1974, which could perhaps be alleviated through fair salary compensation.

Health Facility Policies and Principles: Poor health facilities and inadequate hospital principles can contribute to job dissatisfaction among nurses, which can impact one's intent to leave. The more a hospital is lacking in principles, the more likely nurses will be dissatisfied with their jobs and plan to leave the profession.

Commitment to an Organization: Another study identified that strong commitment to an organization positively impacted nurses' job satisfaction, which led to a reduction in desires to leave. However, a lack of organizational commitment increased the intent to leave.

Work Environment: In one study, work environment had a relatively minor effect on the intent to leave. The types of work environment issues identified as influencing one's intent to leave include the size and design of an individual's workspace. Attraction to other jobs and/or professions may also contribute to leave intentions and turnover among nurses. In particular, nurses may find that they are attracted to a similar job to that of their 
colleagues either due to a better work environment or because the job is more suitable. This could mean that a nurse may pursue further education and training in another profession to obtain a more desirable career.

Clinical Challenges: One study identified a lack or excess of clinical challenges as potentially affecting intentions to leave. When nurses feel they are not adequately challenged at work, they are more likely to be disillusioned with their roles, which can lead to a desire to leave. On the other hand, excessive challenges can place undue stress on nurses, leading to job dissatisfaction and the desire to seek work elsewhere.

Professional Development: The greater the opportunity for professional development in the workplace, the less likely nurses plan to leave their job, especially among younger, less experienced nurses. New graduates tend to value organizations that contribute to their career development and are less likely to be dissatisfied with their job if they grow into their role. Thus, professional development opportunities can help reduce job dissatisfaction and foster organizational commitment.

Job Security: Actual and perceived job security also impacts one's desire to leave a job. One study found that the more secure a nurse felt about his or her job, the more likely he or she was satisfied with the job and willing to stay with the organization. The value placed on job security, however, is generation dependent, with nurses born after 1960 valuing job security more than nurses born between 1946 and 1959 .

Poor Quality of Care: Deteriorating quality of care in an organization, such as a hospital, is associated with intentions to leave and nursing turnover. For instance, in one study, nurses in poorly staffed hospitals were $75 \%$ more likely to report poor or fair quality care than nurses in better staffed hospitals. Improvements to care quality may therefore positively reduce turnover rates.

Workload: In one study, both the amount and type of work performed affected one's intent to leave. Excessive levels of work and/or uninteresting or unchallenging work may lead to job dissatisfaction, which facilitates a desire to seek alternative employment.

Job Dissatisfaction and Burnout: Together, job dissatisfaction and burnout contribute to nurses' intentions to leave. More than $50 \%$ of young nurses in one study were dissatisfied with their jobs. Another study also identified job satisfaction as a major contributor to nurses' intent to leave. Conversely, one study observed only a minor correlation between job dissatisfaction and nurses' intent to leave. Burnout and emotional exhaustion have also been identified in several studies as significantly contributing to job/professional resignation. For instance, one study concluded that emotional exhaustion affected over $50 \%$ of nurses surveyed [29], particularly those who were young and inexperienced. Similar results have also been highlighted in other studies. Graduate nurses, in particular, face great stress during their first year of employment. Here, nurses confront a steep learning curve. At the same time, turmoil and surprises are realities of their practice. In another study of newly graduated nurses, burnout was a leading cause of resignation toward the latter stages of employment.

Burnout and job dissatisfaction are related; together, they influence nurses' intentions to leave the profession. Psychological distress and cumulative fatigue impact nurses' intent to leave. Burnout can also influence several factors related to turnover, including interpersonal conflicts, skill mismatches and excessive workload. Likewise, a lack of cooperation among nurses and other health professionals within hospital environments leads to burnout and job dissatisfaction, which can significantly impact turnover.

\section{Discussion}

\section{Interactions between Contributing Factors}

No single factor, on its own, fully explains the shortage of nurses in Japan. Nurses quit their job and/or leave the profession for various reasons. Obtaining a comprehensive understanding of the motives for nurses leaving their jobs is inevitably complex. The context and circumstances surrounding each individual nurse will impact his or her decision to stay in a job and/or overall profession. The present analysis observed that intentions to leave and turnover are inextricably linked to various factors, which all contribute to the nursing shortage in Japan. For instance, inexperience, burnout, and job dissatisfaction are all linked to the delivery of poor healthcare. Specifically, burnout and work engagement are strongly related to both job and career satisfaction, as well as intentions to leave. Moreover, it appears that nurses who work in inadequately staffed units often express job dissatisfaction, stress, and burnout, which prompt them to seek new employment. Thus, future studies should be carried out to explore the significance of these factors in relation to nursing turnover in Japan.

Burnout is consistently associated with nurses' intentions to leave their profession within and across European countries. Low staff to patient ratios and poor working relationships with physicians are linked to burnout. Unsatisfactory nurse-physician relationships, leadership, a lack of participation in hospital affairs, older age, male gender and part-time positions seem relevant at a global level, but results from studies are highly variable within individual countries, suggesting a need to specifically investigate these factors in relation to a Japanese context. The interactions between different personal, socio-cultural, organizational, and other factors are likely impacting nurses' desires to leave the profession and turnover in a manner that is both unpredictable and difficult to quantify. Moreover, causes for nurses' resignations may vary across time, depending on the direction of a particular nurse's career.

Further research needs to be conducted as to address the varying factors affecting nurses' decisions to resign from their jobs and pursue other careers. One area of focus could be the impact of workload on a nurse's intent to leave. Too few studies have considered the interaction between workload and intent to leave. Thus, factors impacting nurses' decision-making processes need to be carefully studied and understood by hospital employers and managers in order to address such nursing shortages. Another 
issue requiring further research is an investigation into the types of professions nurses pursue after leaving nursing and the reasons for choosing alternative careers. The specific job/career characteristics among alternative options should be compared to the benefits and limitations of nursing so as to gain further insight into the motivation's nurses have for such alternative pursuits.

\section{Strategies for Addressing Intent to Leave/Turnover}

Considering that so many different factors contribute to intent to leave and turnover among nurses, it is inevitable that various strategies will need to be implemented to address nurse shortages resulting from high turnover. The study suggests that health and well-being courses designed to improve positive thinking for nurses may contribute to reducing their work-related stress and burnout. Acknowledging the efforts and contributions of nurses to the profession, career development and collegial approaches to management are also likely to have a significant positive influence on the intention to leave, and reduce turnover. Morale among nurses may be promoted by improving the relations between nurses and physicians. Physicians could be trained in acknowledging the efforts and contributions of nurses to the health profession. All participants in the delivery of quality health care need to be recognized by the system, to make it work more effectively. Managerial development too may lower turnover among nurses, particularly new graduates and less experienced nurses. Sound relations between nurses and their peers can also effectively reduce negative influences on nurse turnover.

Career progression and professional development may also have an impact. Training of younger inexperienced nurses may reduce the level of turnover in the profession (Lee, et al., 2009). Training of younger inexperienced nurses not only alleviates burnout among young nurses, but it also contributes to an improvement in interpersonal relations within hospitals. Education on understanding gender and intergenerational differences may also contribute to reducing nurse turnover and improving nurses' work environments (Takase, et al., 2009). Further, to reduce the exit of women from the nursing profession, strategies need to be developed to address burnout and work/life balance. Practical work experience, career development and/or educational programmers (for example, gender studies) may assist.

\section{Recommendations for Future Research}

A number of studies have been undertaken which show that the factors affecting nursing turnover in Japan encompass personal, socio-cultural and organizational elements. Therefore, longitudinal studies are needed which explore more deeply and monitor these factors that are not static but changing over time. Furthermore, it would be helpful to carry out qualitative inquires examining the impact of nursing turnover on the well-being and productivity of those that remain in the workforce. In order to better understand how changing societal and work conditions over time lead nurses to leave a post or the profession, researchers might employ narrative methods to collect and analyses their stories. In general, more research is warranted in order to better understand turnover behavior and how turnover within the skilled nursing workforce impacts the capacity of the health sector to respond to the increasing demands for health care.

\section{Conclusion}

Generalizations about each particular nurse's decision to leave their job or the profession are difficult to make. The interplay between various subjective and objective factors lead each particular nurse to decide to leave their job or the profession. The manner in which a nurse describes their decision to leave too may have a bearing on the analysis. All this makes it difficult to assess each separate factor contributing towards nurses' intent to leave. However, certain common threads have been identified in the literature both in Japan and more generally internationally. These include interpersonal relations, skills mismatch and poor quality of care to name a few. Other factors, however, also contribute. Ultimately, each factor may have a varying degree of influence to each individual's decision to resign. When many individuals decide to leave a profession though, an analysis of the factors determining the decision need to be considered - particularly when the profession is significant to society and the health and well-being of its members. Delivery of quality health care becomes critical as it becomes more difficult to attract and retain nurses. High nurse turnover can be costly and detrimental to society, imposing a heavy burden on the delivery of health care. Attempting to find a solution to the supply factors contributing to nurses leaving the profession is not only a worthwhile pursuit for the profession, but more critically for society generally. Nurses must feel valued in their job and must feel like they are contributing. Only then will the quality of health care in society improve and Japan's and other nations' welfare progress and advance.

\section{References}

1. (2017) Ministry of Health, Labour and Welfare. Heisei 25 nen waga-kuni no hoken-toukei. MHLW, Tokyo.

2. Dawson A, Stasa H, Roche M, Homer C, Duffield C (2014) Nursing churn and turnover in Australian hospitals: nurses' perceptions and suggestions for supportive strategies. BioMed Central 13(1): 11.

3. Shields A, Ward M (2001) Improving nurse retention in the National Health Service in England: the impact of job satisfaction on intentions to quit. Journal of Health Economics 20(5): 677-701.

4. Hayes L, O Brien Pallas L, Duffield C, Shamian J, Buchan J, et al. (2006) North N, Stone P. Nurse turnover: a literature review. International Journal of Nursing Studies 43(2): 237-263.

5. Ohue T, Moriyama M, Nakaya T (2011) Examination of a cognitive model of stress, burnout, and intention to resign for Japanese nurses. Japan Journal of Nursing Science 8(1): 76-86.

6. (2010) International Council of Nurses. The impact of turnover and the benefit of stability in the nursing workforce. Geneva, USA.

7. (2017) Cambridge University Press. Cambridge online dictionary, Cambridge Dictionary online.

8. Estryn Behar M, Van der Heijden B, Oginska H, Camerino D, Le Nezet 0 , et al. (2007) The impact of social work environment, teamwork characteristic, burnout, and personal factors upon intent to leave among European nurses. Medical Care 45(10): 939-950.

9. Bhuian S, Menguc B (2002) Evaluation of job characteristics, organizational commitment and job satisfaction in an expatriate, guest worker, sales setting. Journal of Personal Selling and Sales Management 22: $1-12$. 
10. Coomber B, Barriball K (2007) Impact of job satisfaction components on intent to leave and turnover for hospital-based nurses: a review of the research literature. International Journal of Nursing Studies 44(2): 297-314.

11. Purani K, Sahadev S (2008) The moderating role of industrial experience in the job satisfaction, intention to leave relationship: an empirical study among salesmen in India. Journal of Business \& Industrial Marketing 23(7): 475-485.

12. Prestholdt P, Lane I, Mathews R (1987) Nurse turnover as reasoned action: development of a process model. Journal of Applied Psychology 72(2): 221-227.

13. (2010) Deutsche Agentur für Health Technology Assessment des. Differential diagnostik des burnout-syndromes. DIMDI Köln.

14. (2010) Ministry of Health, Labour and Welfare. Dai 7 ji kangosyokuinjukyu-mitoshi ni kansuru kentoukai dai 6 kai shiryou, Tokyo.

15. (2016) Japanese Nursing Association. Heisei 27 nen kango-kankeitoukei-shiryousyu, Tokyo.

16. Kaino T, Kanedani Y, Hashizaki H, Matsumoto K (2008) Senzaikangoshi wo ikani genbahukki saseruka. ISFJ Policy Forum.

17. (2014) Ministry of Health, Labour and Welfare. Dai 1 kai kangosyokuinjukyu-mitoshi ni kansuru kentoukai, Tokyo.

18. (2014) Ministry of Health, Labour and Welfare. Dai 103 kai kangosikokkasiken (tsuika-shiken) no goukaku-happyou nitsuite Tokyo.

19. Rondeau K, Williams E, Wagar T (2008) Turnover and vacancy rates for registered nurses: do local labor market factors matter? Health Care Management Review 33(1): 69-78.

20. Lavoie Tremblay M, Paquet M, Marchionni C, Drevniok U (2011) Turnover intention among new nurses: a generational perspective. Journal for Nurses in Staff Development 27(1): 39-45.

21. Moher D, Liberati A, Tetzlaff J, Altman D, PRISMA Group (2009) Preferred reporting items for systematic reviews and meta-analyses: the PRISMA statement. Annals of Internal Medicine 151(4): 264-269.

22. Popay J, Roberts H, Sowden A, Petticrew M, Arai L, et al. (2006) Guidance on the conduct of narrative synthesis in systematic reviews: a product from the ESRC methods programme. Institute of Health Research: Lancaster.

23. (2006) Public Health Resource Unit. The critical skills appraisal programme: making sense of evidence. Oxford.

24. Law M, Stewart D, Letts L, Pollock N, Bosch J, et al. (1998) Guidelines for critical review form: qualitative studies. ON: McMaster University Occupational Therapy Evidence-Based Practice Research Group.

25. Takase M, Yamashita N, Oba K (2007) Nurses leaving intentions: antecedents and mediating factors. Journal of Advanced Nursing 62(3): 295-306.

26. Tei Tominaga M, Miki A (2008) A longitudinal study of factors associated with intentions to leave among newly graduated nurses in eight advanced treatment hospitals in Japan. Industrial Health 48(3): 305-316.

ISSN: 2574-1241

DOI: $10.26717 / B J S T R .2018 .12 .002258$

Yoshiyuki Nagaya. Biomed J Sci \& Tech Res

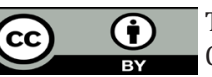

This work is licensed under Creative

Commons Attribution 4.0 License

Submission Link: https://biomedres.us/submit-manuscript.php
27. Takase M, Oba K, Yamashita N (2009) Generational differences in factors influencing job turnover among Japanese nurses: an exploratory comparative design. International Journal of Nursing Studies 46(7): 957-967.

28. Kudo Y, Satoh T, Sinji H, Miki T, Watanabe M, et al. (2006) Factors associated with turnover intention among nurses in small and mediumsized medical institutions. Environmental Health and Preventive Medicine 11(3): 128-135.

29. Kanai Pak M, Aiken L, Sloane D, Poghosyan L (2008) Poor work environments and nurse inexperience are associated with burnout, job dissatisfaction and quality deficits in Japanese hospitals. Journal of Clinical Nursing 17(24): 3324-3329.

30. Suzuki E, Tagaya A, Ota K, Nagasawa Y, Matsuura, et al. (2010) Factors affecting turnover of Japanese novice nurses in university hospitals in early and later periods of employment. Journal of Nursing Management 18(2): 194-204.

31. Takase M, Nakayoshi Y, Teraoka S (2012) Graduate nurses' perceptions of mismatches between themselves and their jobs and association with intent to leave employment: a longitudinal survey. International Journal of Nursing Studies 49(12): 1521-1530.

32. Ishihara I, Ishibashi Y, Takahashi K, Nakashima M (2013) Effect of organizational factors and work environments on newly graduated nurses' intention to leave. Japan Journal of Nursing Science.

33. Ushiro R, Nakayama K (2010) Gender role attitudes of hospital nurses in Japan: their relation to burnout, perceptions of physician-nurse collaboration, evaluation of care, and intent to continue working. Japan Journal or Nursing Science 7(1): 55-64.

34. Vahey D, Aiken L, Sloane D, Clarke S, Vargas D (2004) Nurse burnout and patient satisfaction. Medical Care 42(2): 57-66.

35. Peterson U, Demerouti E, Bergstrom G, Samuelsson M, Asberg M, et al. (2008) Burnout and physical and mental health among Swedish healthcare workers. Journal of Advanced Nursing 62(1): 84-95.

36. Toh S, Ang E, Devi M (2012) Systematic review on the relationship between the nursing shortage and job satisfaction, stress and burnout levels among nurses in oncology/hematology settings. International Journal of Evidenced-Based Healthcare 10(2): 126-141.

37. Heinen M, Achterberg T, Schwendimann R, Zander B, Matthews A, et al. (2013) Nurses' intention to leave their profession: a cross sectional observational study in 10 European countries. International Journal of Nursing Studies 50(2): 174-184.

38. Corley M, Minick P, Elswick R, Jacobs M (2005) Nurse moral distress and ethical work environment. Nursing Ethics 12(4): 381-390.

39. Lee T, Tzeng W, Lin C, Yeh M (2009) Effects of a preceptorship programme on turnover rate, cost, quality and professional development. Journal of Clinical Nursing 18(8): 1217-1225.

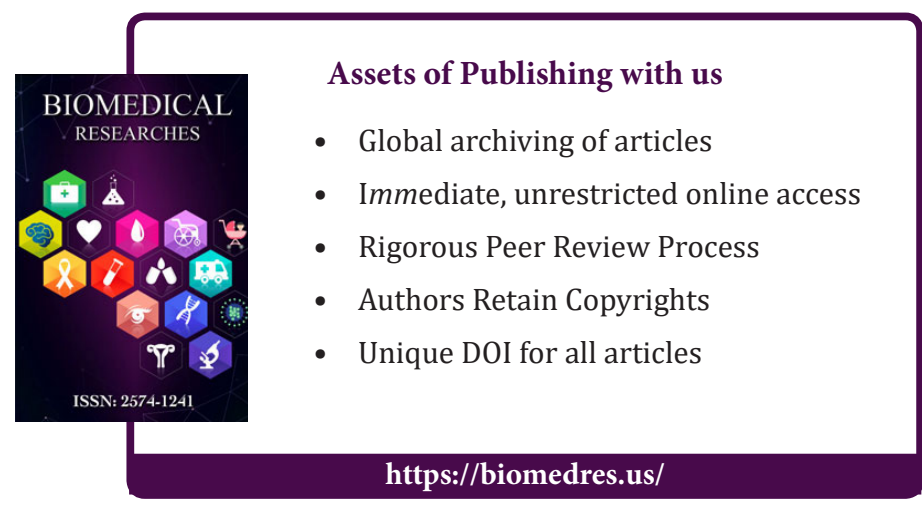

Cite this article: Yoshiyuki Nagaya. A Review of Factors Affecting Nursing Turnover in Japan. Biomed J Sci \& Tech Res 12(3)-2018. BJSTR. 